University of Nebraska - Lincoln

DigitalCommons@University of Nebraska - Lincoln

Publications from USDA-ARS / UNL Faculty

U.S. Department of Agriculture: Agricultural

Research Service, Lincoln, Nebraska

February 1969

\title{
Penicillium urticae Bainier Enumeration in Soils
}

Fred A. Norstadt

T. M. McCalla

Follow this and additional works at: https://digitalcommons.unl.edu/usdaarsfacpub

Part of the Agricultural Science Commons

Norstadt, Fred A. and McCalla, T. M., "Penicillium urticae Bainier Enumeration in Soils" (1969).

Publications from USDA-ARS / UNL Faculty. 162.

https://digitalcommons.unl.edu/usdaarsfacpub/162

This Article is brought to you for free and open access by the U.S. Department of Agriculture: Agricultural Research Service, Lincoln, Nebraska at DigitalCommons@University of Nebraska - Lincoln. It has been accepted for inclusion in Publications from USDA-ARS / UNL Faculty by an authorized administrator of DigitalCommons@University of Nebraska - Lincoln. 


\section{SHORT COMMUNICATION}

\section{Penicillium urticae Bainier Enumeration in Soils *}

\section{Introduction}

Studies of stubble-mulched soils from three locations in Nebraska showed larger total counts (bacteria and actinomycetes) and fungi than in plowed soils ${ }^{3}$ 6. Penicillium uvticae Bainier numbers increased in subtilled soil compared with either plowed soil or subtilled soil with crop residues removed.** $P$. urticae $\mathrm{B}$. produces patulin, a phytotoxic substance. This organism is regarded as one of the possible sources of the toxicity problem arising in stubble mulching ${ }^{45}$. Penicillium expansum Link and patulin were studied in the apple replant problem ${ }^{2}$.

The purpose of this paper is to present methods to estimate $P$. urticae $\mathrm{B}$. numbers in soils and demonstrate patulin in selected fungal isolates.

\section{Soil plating and isolation}

A special layering and culture technique ${ }^{\dagger}$ speeded the growth and sporulation of the fungus in dilution plate counts. Rose bengal agar ${ }^{1}$ plates were poured and hardened. One-milliliter aliquots from the dilution bottles were placed in tubes containing $2 \mathrm{ml}$ of $1 \%$ melted agar at $40^{\circ} \mathrm{C}$. The test tube contents were mixed by rotation between the palms of the hands, and poured over one of the prepared plates. Incubation was at $25^{\circ} \mathrm{C}$.

After making the total fungi counts, the plates were warmed to room temperature (about $25^{\circ} \mathrm{C}$ ) and exposed to room light each day and cooled to $5^{\circ} \mathrm{C}$ each night for a total of 10 to 14 days. $P$. urticae B. ${ }^{7}$ was identified by colony and growth characteristics. Identity of $P$. urticae B. and patulin synthesis were checked by transferring colonies to potato dextrose agar slants in test tubes and incubating 6 days at $25^{\circ} \mathrm{C}$ until abundant sporulation. A $3-\mathrm{mm}$ cube of agar from beneath the slant surface was pressed onto a

* Contribution from the Northern Plains Branch, Soil and Water Conservation Research Division, Agricultural Research Service, USDA, in cooperation with the Nebraska Agricultural Experiment Station, Lincoln. Published as Paper No. 2275, Journal Series, Nebraska Agricultural Experiment Station.

** Unpublished data, Fred A. Norstadt and T. M. McCalla.

$\dagger$ Layering technique adapted from a suggestion made by Dr. Thomas L. Thompson of the Department of Microbiology, University of Nebraska, Lincoln. 
$23-\times 28.5-\mathrm{cm}$ sheet of Whatman * No. 1 chromatography paper at $2.5-\mathrm{cm}$ intervals and the agar dried. Patulin was spotted on each sheet at $20 \mu \mathrm{g}$ per spot. The control patulin, authenticated by melting point and infrared and ultraviolet spectroscopy, had been isolated ${ }^{5}$ from cultures of $P$. urticae $B$. Chromatograms were stored under helium to avoid reaction with traces of ammonia from the air. Ascending development was with an ethyl alcohol : water solvent system $(80: 20 \mathrm{v} / \mathrm{v})$. The developed chromatograms were dried and exposed to ammonia by suspending them over a $1-\mathrm{cm}$ layer of concentrated ammonium hydroxide solution contained in an aluminium foil-covered glass cylinder. Exposing the chromatograms to ultraviolet light (3600 $\AA$ ) revealed the fluorescence of authentic patulin which could be compared with fluorescent spots from the chromatographed culture media as to color and Rf value ${ }^{5}$.

\section{Infrared analysis for patulin}

The presence of patulin also was confirmed by infrared analysis of an extract. Potato dextrose broth in 50-ml quantities was inoculated with the isolates to be tested. After growth at $25^{\circ} \mathrm{C}$ for 14 days, the culture fluid was separated by decantation and filtration through a Büchner funnel with suction, using a rapid filter paper. The culture fluid was extracted twice with $50-\mathrm{ml}$ portions of ethyl acetate in a separatory funnel and the combined extracts dried over $8 \mathrm{~g}$ of anhydrous $\mathrm{MgSO}_{4}$,** The extract, separated from the drying agent, was evaporated by vacuum to approximately $10 \mathrm{ml}$. About 0.1 to $0.2 \mathrm{ml}$ was allowed to evaporate on a $5 \times 5 \times 0.5-\mathrm{cm}$ slab of optical grade $\mathrm{NaCl}$ in a nearly circular area $1 \mathrm{~cm}$ in diameter. The $\mathrm{NaCl}$ slab was placed in an infrared spectrophotometer to examine the 5 to 6 micron region for the spectrum of patulin ${ }^{8}$.

\section{Bioassay and patulin assay}

Chromatograms not exposed to ammonia vapors were bioassayed with Cheyenne winter wheat seeds (Triticum aestivum L.). The sections of the chromatograms containing authentic and suspected patulin from fungal isolates were placed on sterile, double-germinating paper liners in petri dishes. Blank chromatography paper for controls also was developed. Five wheat seeds were placed on the chromatography paper in a star-shaped arrangement with the embryo ends in the center. The germinating paper was saturated with distilled water. The seeds were germinated for 3 days at $25^{\circ} \mathrm{C}$. Bioassay response was calculated as percent elongation of the wheat roots of the treatment compared with the control.

The patulin concentration in the agar was estimated after two-dimensional chromatography by a previously reported technique ${ }^{6}$.

\footnotetext{
* Trade name is included to provide specific information and does not imply endorsement of the product listed by the agencies concerned.

** $\mathrm{MgSO}_{4}, 7 \mathrm{H}_{2} \mathrm{O}$ dried for 2 hours at $500^{\circ} \mathrm{C}$.
} 


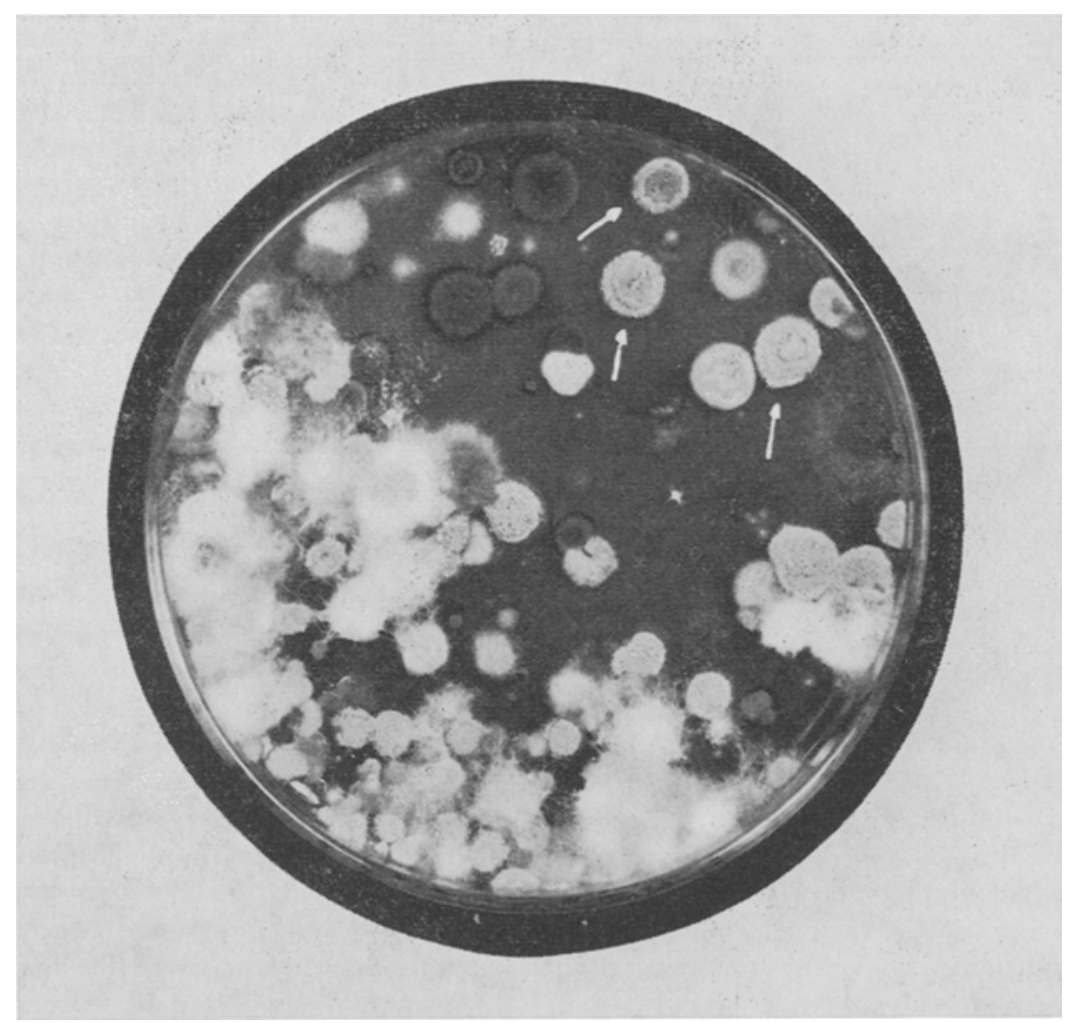

Fig. 1. Soil fungi growing in a layered, 2-week-old rose bengal plate. The arrows point to three colonies of Penicillium urticae Bainier among 26 visible colonies of this fungus. (Kodak Royal Pan film*).

\section{Resulis and discussion}

In Figure 1, the arrows point to $P$. urticae B. among other soil fungi. Placing the inoculum in a thin agar layer on the deep reserve agar had two purposes: (a) the colonies needed only to grow through a thin agar layer to sporulate, and they matured more uniformly; and (b) the deep reserve agar and the nightly storage at $5^{\circ} \mathrm{C}$ permitted sufficient time for the characteristic fungal growth. The cyclic incubation at two temperatures $\left(25^{\circ} \mathrm{C}\right.$ and $\left.5^{\circ} \mathrm{C}\right)$ favored the growth and sporulation of $P$. urticae B. over that of other fungi. $P$. urticae $B$. can grow and sporulate at $5^{\circ} \mathrm{C}$ in 2 to 3 weeks. Fungal coloration, diurnal growth, and other colony features greatly facilitated identification and counting of P. urticae B.

\footnotetext{
* f/22 lens opening at $1 / 4$ second using two No. 1 white photoflood bulbs.
} 
TABLE 1

\begin{tabular}{|c|c|c|c|}
\hline \multicolumn{2}{|l|}{$\begin{array}{l}\text { Rf and bioassay values obtained for authentic patulin and } \mathrm{NH}_{3} \text {-reacting and UV- } \\
\text { fluorescing sections from chromatography of patulin and agar * from slants of } \\
\text { fungal isolates of Penicillium urticae Bainier }\end{array}$} \\
\hline \multirow{3}{*}{ Source } & Rf ** & $\begin{array}{c}\text { Bioassay } \\
\text { response of roots } \\
\% \text { of control }\end{array}$ & $\begin{array}{c}\text { Patulin } \\
\text { quantity } \\
\mu \mathrm{g}\end{array}$ \\
\hline Authentic patulin & 0.87 & 80 & 20 \\
Isolate 1 & 0.86 & 90 & 10 \\
2 & 0.86 & 70 & 30 \\
3 & 0.86 & 82 & 14 \\
4 & 0.86 & 82 & 14 \\
\hline
\end{tabular}

* Potato dextrose agar for 6 days at $25^{\circ} \mathrm{C}$.

** Ethanol : water (80:20 v/v) ascending.

Results of the chromatography and bioassay of agar medium from $P$. utricae $\mathrm{B}$. are presented in Table 1 . The $R_{f}$ values for the $\mathrm{NH}_{\mathbf{3}}$-reacting and UV-fluorescing sections of the chromatograms agreed with that of authentic patulin. Bioassay must be done on sections not exposed to ammonia vapor as patulin is inactivated by ammonia.

Invariably, the potato dextrose agar from $P$. urticae $B$. markedly reduced root and shoot growth compared with controls in a bioassay. Sterile agar medium did not affect germination. Root growth was affected more than shoot growth. Visible effects on roots included necrosis, browning, excessive root hair development, shortening, and curling and twisting of the roots. Cheyenne winter wheat in distilled water normally developed 3 seminal roots, but patulin in the order of 9 ppm caused 4 to 5 seminal roots to develop in the same interval. Patulin acted as an auxin synergist in a coleoptilesection test ${ }^{5}$.

Infrared analysis of an impure extract of culture fluid provided a rapid method for patulin analysis. This technique did not require an involved procedure to obtain a purified material such as for a melting point determination or functional group analysis by chemical means.

\section{Summary}

A dilution plating method estimated Penicillium urticae Bainier numbers in soil. This method, which used an agar layering technique and a cyclic incubation of 8 hours at room temperature (about $25^{\circ} \mathrm{C}$ ) and 16 hours at $5^{\circ} \mathrm{C}$, permitted the differential growth and sporulation in favor of $P$. urticae $\mathrm{B}$. over other common soil fungi.

Procedures of extraction, paper chromatography, infrared analysis, and bioassay assayed for accumulated patulin. A combination of these methods 
routinely estimated $P$. urticae B. numbers in soils and authenticated patulin production by selected isolates.

Received April 16, 1968

Fred A. Norstadt and T. M. McCalla *

\section{References}

1 Allen, O. N., Experiments in Soil Bacteriology. Burgess Publishing Co., Minneapolis, Minnesota (1957).

2. Börner, H., Phytopathol. Z. 49, 1-28 (1963).

3 Dawson, R. C. et al., Nebraska Agr. Expt. Sta. Research Bull. 155 (1948).

4 McCalla, T. M., et al., 8th Intern. Congr. Soil Sci. Soc. Proc., 933-943 (1964).

5 Norstadt, Fred A. and McCa1la, T. M., Science 140, 410-411 (1963).

6 Norstadt, Fred A. and McCalla, T. M., Soil Sci. Soc. Am. Proc. 32, 241-245 (1968).

7 Raper, K. B. and Thom, C., A Manual of the Penicillia. Williams and Wilkins Co., Baltimore, Md. (1949).

8 Woodward, R. B. and Turbakhsh, Singh, J. Am. Chem. Soc. 71, 758-759 (1949).

* Soil Scientist, USDA, Grand Junction, Colorado (formerly Chemist, USDA, Lincoln, Nebraska); and Microbiologist, USDA, Lincoln, Nebraska, respectively. 